\title{
From resentment to excitement - Australasian students' perception towards a sales career
}

\author{
Brian Handley, Tekle Shanka and Fazlul K. Rabbanee \\ Curtin University
}

\begin{abstract}
Purpose: This study aims to explore Australasian students' current perception towards a sales career.

Methodology: Data was collected through a self-administered survey from 431 students enrolled in a Sales Management unit in a large Australian university and its Asian campuses.

Findings: The study reveals a 4-factor solution with factors labelled as 'exciting', 'deceptive', 'taxing', and 'challenging'; with 'exciting' being the only factor to significantly predict likelihood of pursuing a sales career. Although no differences of perception were found between males and females, Asian students were found to perceive sales career as more exciting, innovative and fun than Australian students.
\end{abstract}

\section{Implications:}

The four factors that were found to influence students' perception towards a sales career are novel, psychometrically sound, and are pertinent for businesses conducting graduate recruitment. The study also indicates how sales education at university level assist in changing students' views towards a sales career from negative to positive.

Originality: While previous research has reported negative perceptions about sales as a career, this study reveals that students consider sales to be an 'exciting' career.

Limitations: Although significant difference was noted between Australian and Asian students' perceptions towards sales as an exciting career, it is prudent to interpret and generalize our finding with caution as Asia is the largest continent with different cultures, religions and races.

Key words: Sales management, Students' perceptions, Australia, Asia, and Marketing.

Paper type: Research paper 


\section{Introduction}

Selling has been a critical marketing activity that accounts for a major portion of revenue generation for any company (Barat and Spillan, 2009; Concha et al., 2014). However, a review of the literature suggests that sales still falls short of being recognized as a profession by society with numerous studies over a period of sixty years reporting negative views of sales as a career (Mason, 1965; Paul and Worthing, 1970; Dubinsky, 1980; Honeycutt et al., 1999; Wiles and Spiro, 2004; Caballero and Joonas, 2009; Waldeck et al., 2010; Bahhouth et al., 2011). In recent times, it is believed that these negative images have been reinforced through anecdotes, stories, and the mass media focussing on the business-to-consumer salesperson resulting in all salespeople being stereotyped in a similar manner, perpetuating the myth of the 'door to door' sales person. For example Hartman (2006) found that television and movies have consistently characterized salespeople in terms that are stereotypical and negative i.e. ('deceptive', 'shady' and 'villains'). In doing so the author narrowly defined the task requirements of professional salespeople. These stereotypical representations imply that a sales person personifies some of society's most despised characteristics i.e. greed, deception, distrust, and selfishness (Hartman, 2006).

Sales managers and recruiters, therefore, face the dilemma of trying to combat these engrained negative perceptions as they start to reposition their sales forces with an emphasis on customer relationship management (Marcos-Cuevas et al., 2014), and the significant shift towards customer-centric marketing (Oviedo-Garcia, 2007; Bristow and Gulati, 2002). However, results to date indicate that recruitment agencies face an uphill battle in trying to fill sales positions (Agnihotril et al., 2014). In response to this, many universities are being encouraged by corporations and recruiters to offer sales education courses for those interested in pursuing a career in sales, (Bolander et al., 2014; Peltier et al., 2014; Gray et al., 2012; Leasher and Moberg, 2008). 
Sales education in universities equip students with crucial job-related skills and contributing to sales representatives' performance (Bolander et al., 2014) through the establishment of sales centres (Stewart, 2006; Mantel et al., 2002). However, it is thought that university students may still hold stereotypes (Bahhouth et al., 2011) based on external influences. If students have concerns regarding poor ethical image of sales (Burnett et al., 2008) or inaccurate stereotypes about the nature of sales, they are less likely to consider selling as a career (Cummins et al., 2015; DelVecchio and Honeycutt, 2002; Sparks and Johlke, 1996). This may have an adverse effect on the recruitment of high quality applicants to selling jobs (Bahhouth et al., 2011).

Although prior research has advanced the literature on students' intent to pursue a sales career, shortcomings still remain (e.g., Bristow et al., 2011; Karakaya et al., 2011). For example, existing research does not specify different inherent aspects of a sales job that may attract students to pursue a career. Peltier et al. (2014) warranted further research to elicit the underlying motivation to pursue a sales career. Moreover, existing research is largely silent whether prevailing stereotypical negative views toward sales as a career has changed in recent times among the university students. Besides, past studies are somewhat quiet as to whether new age students' perception towards a sales career differs across cultures. In addition, marketing education literature, thus far, has been relatively less responsive to the needs of both students and employers (DeeterSchmelz and Kennedy, 2011; Anderson et al., 2005; McIntyre and Tanner, 2004).

In this backdrop, the key purposes of this study is (a) to explore current perception of the students towards a sales career; and (b) examine whether such perception influence the likelihood of pursuing a sales career. We attempt to uncover students' current perception of a sales career from a multi-cultural point of view by conducting a survey among the students enrolled in a Sales Management unit at a large Australian University and its various offshore campuses located across 
South East (SE) Asia. The need to better understand the career motivation of $21^{\text {st }}$ century students has increased due to the fact that there is a shortage of sales professionals (Agnihotril et al., 2014; Collins et al., 2012) particularly in light of the demand for new salespeople capable of revenue generation (Concha et al., 2014). Because firms go global as a part of their business strategy (Paul, 2015), the need for skilled sales professionals continues to grow at an average rate of 7-19 percent (Bristow et al., 2011). Therefore, it is timely to address the above mentioned research gaps by exploring students' motivational priorities towards a career in sales to elicit what aspect of sales jobs are preferred (or not) by the students.

In the following sections, we review relevant theories, existing literature and outline the methodology of this study. Following this, data analysis and results of the study are reported, followed by discussion, implications, limitations and then avenues for future research.

\section{Theoretical background and literature review}

Pursuing a sales career can be explained using 'Fit theory' (Chatman, 1991) and Herzberg's (1966) 'two-factor theory of motivation'. Fit theory suggests that an individual's behaviour is influenced by the given situation and the environment (Chatman, 1991) such that a good fit between the individual and the environment will result in higher levels of mental and physical well-being and satisfaction (Carless, 2005; Dawis and Lofquist, 1984; Holland, 1997). There is a level of 'fit' between the tasks associated with a particular job and the worker in an organizational setting. The degree of fit between the skill and ability of the worker and requirements of the specific job are the key determining forces to decide whether to pursue that job or not (Donavan et al., 2004). The 'fit' between an individual and the job itself has previously been associated with low attrition of job applicants in the recruitment process, higher work performance, higher job satisfaction, and lower voluntary turnover (Phillips, 1998; Carless, 2005; Meglino et al., 2000). 
Thus Fit theory suggests that an individual's decision to pursue a specific job is influenced by his or her views of how the job fits with his or her context. Such views of the individual are shaped by his/her psychology such as motivation, which can be explained by Herzberg's (1966) two-factor theory ('satisfier' and 'hygiene' factor). 'Satisfiers' are directly related to the job content and reflect a need for personal fulfilment whereas the 'hygiene factor' is related to the work setting or job context (Herzberg, 1966). The authors therefore argue that students of the $21^{\text {st }}$ century may pursue a sales career due to the inherent nature of the sales job, which is in line with Herzberg's 'satisfier' factors, and contribute to achievement, personal development and fulfilment. Our argument is based on the fact that the students of current generation focus on their own interests (Kelan, 2008) and personal development. They are interested in how things are done (Kelan, 2008) in line with the job itself. They also seek career progression (Eldridge, 2008), which is related to achievement, advancement, and status.

A comprehensive review of the literature found that attitudes towards a sales career has been a subject of interest to marketing educators and researchers for more than sixty years with numerous studies reporting negative views of sales as a career, (Mason, 1965; Paul and Worthing, 1970; Dubinsky, 1980; Honeycutt et al., 1999; Wiles and Spiro, 2004; Caballero and Joonas, 2009; Waldeck et al., 2010; Bahhouth et al., 2011, Agnihotril et al., 2014). It is thought that these negative perceptions of sales people may have emerged during a period often referred to as the 'sales era' when aggressive attempts were used by organizations to sell their products in a cutthroat competitive environment where supply exceeded demand (Kerin et al., 2009).

However, recent research indicates that sales still falls short of being recognized as a profession (Waldeck et al., 2010; Hawes et al., 2004). Sales is still being characterised as low in prestige (Bristow et al., 2006), biased perception (Bahhouth et al., 2014; Bahhouth et al., 2013; 
Bahhouth et al., 2011; Bahhouth et al., 2014) involving manipulation of others (Lysonski and Durvasula, 1998), being unethical (Lee et al., 2009; Pettijohn et al., 2007; Klein et al., 2006; Hawes et al., 2004), misrepresenting guarantees/warranties, taking advantage of uneducated buyers, exaggerating product benefits, selling products that are not needed, and exaggerating (Bristow et al., 2006; Kavas, 2003).

These negative stereotypes (Leasher and Moberg, 2008) are not restricted to one country, with international studies finding that selling was not considered to be an attractive career (Agnihotril et al., 2014, Barat and Spillan, 2009; Lee et al., 2007) even in developing nations (Bahhouth et al., 2013). However, there is no reason to expect that stereotypes will be consistent across cultures; for example, McGarty et al. (2002) and Yoon et al. (2000) consider that stereotypes held in one culture are not necessarily the same as those held in others due to the cultural environment i.e. Asian versus Western cultural values (Gong, 2003).

Notwithstanding the above stereotypical perceptions, the nature of the sales job has changed significantly over the years (Dixon and Tanner, 2012). Selling is now a critical marketing activity that accounts for a major portion of the revenue generation for any company (Concha et al., 2014; Barat and Spillan, 2009). In order to survive, firms must continue to enhance their performance (Paul and Shrivastava, 2015), which can largely be ensured through skilled sales personnel. Sales managers are becoming increasingly aware of the demands from their customers for added value (Marcos-Cuevas et al., 2014) and the significant shift towards customer-centric marketing (OviedoGarcia, 2007; Bristow and Gulati, 2002).

As a result, companies have started to reposition their sales forces with a focus on customer relationship management, emphasizing on salespeople who are flexible, innovative, persistent, and self-motivated (Lassk et al., 2012; Oviedo-Garcia, 2007); who have initiative to identify and solve 
problems (Frese et al., 1997); who possess emotional wisdom (Bagozzi et al., 2010); who can demonstrate an in-depth knowledge about the customers' business, behaviour, information gathering, market analysis, sales forecasting (Concha et al., 2014); and who are familiar with new technologies (Walker et al., 2009; Bristow and Gulati, 2002). This leads to the emergence of a new breed of young, intelligent, highly trained, motivated, and customer-oriented people (Lassk et al., 2012; Bush et al., 2014) having a winning combination of customer insight, industry knowledge, innovativeness and out-of-the-box thinking capacity (Paul and Shrivastava, 2015). These sales people are capable of learning and adapting quickly (Leasher and Moberg, 2008; Wiles and Spiro, 2004; Stevens and Macintosh, 2003; Amin et al., 1995) and are trained to explain technical concepts or exchange information (Duke, 2002; Bush et al., 2014), and to give quality customer service by utilising empathy and persuasion, rather than aggressive selling techniques (Butaney, 2007; Sojka et al., 2000). This 'new breed' of sales person is far from the negative stereotypical views reported in previous research. These 'new age' sales people have become relationship managers, knowledgeable partners, strategic decision makers (Karakaya et al., 2011) and are capable of revenue generation (Concha et al., 2014) as sales moves from 'transaction' to 'relationship building' and 'partnering' (Hair et al., 2009).

To accommodate this 'new wave' of professional selling, a major challenge for the firms is to actively search for talented people from diverse backgrounds to fill vacant positions (Agnihotril et al., 2014; Collins et al., 2012; Galea, 2005). Firms believe that such sales people can bring about changes and drive new growth opportunities and innovative business practices (Claar et al., 2009), which results in an increased demand for those equipped with crucial job - related sales skills (Luthy, 2000; Pettijohn and Pettijohn, 2007). For example, Dwyer et al., (1998) found that industrial buyers are often more comfortable purchasing from industrial sellers of similar racial identities. This is not dissimilar to many businesses in the USA where workforces are being 
augmented with an increasing number of racially diverse employees. With this in mind, sales recruiters are looking at diversifying their sales force (Waldeck et al., 2010; Tanner et al., 2008), by attracting university students from diverse backgrounds as excellent sources of prospective salespeople (Nachnani and Ashok, 2007; Bristow et al., 2006) for entry level sales positions.

However, it is thought that university students may still hold negative stereotypes (Bahhouth et al., 2011) influenced by external parties. i.e. parents, (Caballero and Joonas, 2009), friends, (Roach et al., 2011; Spillan et al., 2011) or who review a sales career along more historical lines of selling such as cold-calling, delivery, order-taking, or missionary sellers. This is happening despite the fact that key account management (Blythe, 2005) and consulting styles of selling have evolved in various industries, and are considerably different from more traditional ideas of business to business and business to consumer personal selling (Lee et al., 2007; Blythe, 2005). If today's students have concerns regarding the poor ethical image of sales (Burnett et al., 2008) or inaccurate stereotypes about the nature of sales, they are less likely to consider sales as a career (Cummins et al., 2015; DelVecchio and Honeycutt, 2002; Sparks and Johlke, 1996), which may have a harmful effect on the recruitment of high quality applicants to selling jobs (Bahhouth et al., 2011). Consequently, recruitment agencies face an uphill battle in trying to fill sales positions (Agnihotril et al., 2014).

In response to the above, universities are being encouraged by corporations and recruiters to offer courses focusing on sales education (Bolander et al., 2014; Peltier, Cummins et al., 2014; Gray et al., 2012; Leasher and Moberg, 2008). Consequently, the number of universities offering sales courses has grown dramatically over the years (Knights et al., 2014). These courses assist in equipping students with crucial job related skills and contribute to sales representatives' performance (Bolander et al., 2014) through the establishment of sales centres (Stewart, 2006; 
Mantel et al., 2002). Weilbaker and Williams (2006) suggest that these specialized sales programs offer benefits to both students and the hiring firms (Deeter-Schmelz and Kennedy, 2011). Sales education at universities offer students the opportunity to understand the nature of the industry (Stern and Tseng, 2002), and to develop their communication skills (Rahman et al., 2014), public speaking and persuasive writing (Barr and McNeilly, 2002; Duke, 2002, Luthy, 2000). Students who undertake business degrees (Sojka et al., 2000), and those who have been exposed to sales education within their degree (Neeley and Cherry, 2010; Healy et al., 2011; Caballero and Joonas, 2009) are particularly in demand in the job market. Fogel et al. (2012) mentions that graduates from sales education programs perform better (Bolander et al., 2014) and have higher retention rates than those who do not have a sales education background.

\section{Culture and perception of sales}

Today's businesses recognise that sales organizations must be sensitive to cultural differences (Honeycutt and Ford, 1995). In response to this, several studies have examined students' perceptions and attitudes towards sales career in a variety of cultural settings (Fournier et al., 2014; Bahhouth et al., 2011; Karakaya et al., 2011; Barat and Spillan, 2009; Lee et al.,2007; Honeycutt and Thelen, 2003; Rouzies and Macquin, 2003). Cross-cultural researchers have found that 'culture' influences salespersons' perceptions of intrinsic and extrinsic motivation (DeCarlo et al., 1999), personal selling measures (Herche et al., 1996), decision making, interpersonal trust, and teamwork (Stephens and Greer, 1995). In addition, in a cross-country study between India and Japan, Paul and Shrivastava (2015) found that personality traits and entrepreneurial attributes of MBA students differ based on their country-of-origin as the respondents from developing countries have stronger entrepreneurial intentions than those from developed countries. This indicates that students' perception towards sales career may differ based on their ethnicity or cultural background. 
Therefore, it is expected that differences may exist between Australian and Asian students' perception regarding career preferences due to western individualistic cultural values of Australian people versus the collectivist culture of Asian people.

\section{Methodology}

The data for the study has been collected through a self-administered survey using a structured questionnaire. The survey was administered amongst undergraduate students enrolled in a Sales Management unit in a large Australian university and its Asian campuses. A purposeful survey was conducted among the undergraduate third year students enrolled in a Sales Management unit in its Australian and Asian campuses. The survey was intended to capture the perceptions of all students enrolled in the unit at different campuses as a census, rather than sampling. The survey was conducted in class during the lectures. Although the use of student samples has been criticised in the past (James and Sonner, 2001; Sears, 1986); student samples are still widely used for research (Webster and Sundaram, 1998) and are pertinent to this research. Further, the use of student samples has not been found to generate different results for purchase intention than non-student samples (Ok et al., 2008). A 45-item instrument adapted from Honeycutt et al. (1999) was used on a 7-point Likert scale (1 'strongly disagree' to 7 'strongly agree') and administered in class. Additionally, the questionnaire sought background information such as gender, age, country of birth, prior experience in sales related jobs, and the intention of participants to pursue a career in sales after graduation. The intention to pursue a sales career was measured by a one item scale focusing on the "likelihood of pursuing a sales career" which was anchored on a 7 -point Likert scale. 
Four hundred and thirty one (431) completed questionnaires were received and analysed using SPSS version 19. Profiles of the respondents were such that 59\% were females, with mean age of 21.6 years (range 18-36years); $35.5 \%$ of the respondents' nationality (country of birth) was Malaysia followed by Australia (16.7\%), Indonesia (9.7\%), Singapore (8.6\%), Mainland China (7.7\%), Hong Kong (5.6\%), Mauritius (3.9\%), Thailand (0.7\%) and other (11.6\%). Seventy-two per cent of respondents were majoring in Marketing and of this, $83 \%$ were taking Sales Management as a core unit in their second year of studies. Furthermore, $63 \%$ of respondents report having work experience in retail sales jobs on a part-time basis, and of those (58\%) had less than 12 months' work experience.

Like any other survey based research, this study may suffer from common method variance and the authors adopted various measures in order to minimize its effects. We carefully crafted a cover letter for the survey instrument assuring respondents' anonymity and requesting their honest responses. This helped us to reduce respondents' evaluation apprehension and thus controlled for possible sources of common method bias (Podsakoff et al., 2003). Moreover, we ran Harman's single-factor test and found that the un-rotated factor solution for all the items, generated more than a single factor and lent support to the fact that common method bias is not an issue for this study (Podsakoff et al., 2003). It is difficult to identify the exact source(s) of the common method bias, yet these procedural steps helped us minimize its effect (Roy and Rabbanee, 2015).

\section{Data Analysis and Results}

An exploratory factor analysis (EFA) was conducted in order to identify the underlying dimensions of perceptions of sales as a career. Principal component factor analysis with Varimax rotation (criteria: Eigen value $\geq 1$ and factor loading of $\geq .40$ ) was used under factor analysis to explore the respondents' perception towards a sales career. An iterative procedure of re-running exploratory 
factor analysis (EFA) was followed where items that loaded less than 0.40, and/or that are crossloading on more than one factor were deleted. Such deletion of cross-loaded items is consistent with previous studies (Hair et al., 2010; Sweeney and Soutar, 2001). Finally, a four factor model with 30 items was extracted and named "exciting", "deceptive", "taxing", and "challenging". We named these four factors based on the items that were found to be grouped together in the EFA output. Although "taxing" and "challenging" may be perceived as conceptually overlap with one another, these two factors are distinct from one another. Taxing refers to efforts, energy and difficulties that students usually perceive regarding a sale career, whereas "challenging" refers to the competitive nature of the sales job that challenge one's ability. The remaining two factors: "exciting" and "deceptive" refer to the thrilling and misleading nature of a sales job respectively.

The four factors accounted for $44.91 \%$ of total explained variances. Factor 1 'exciting' consisted of 10 items and accounted for $20.93 \%$ of the total explained variance. Factor 2 'deceptive' consisted of 8 items and accounted for $14.34 \%$ of total explained variance. Factor 3 'taxing' accounting for $5.18 \%$ of the total explained variance consisted of six items. Factor 4 'challenging' consisting of 6 items accounted for $4.46 \%$ of explained variance. The alpha values for all factors ranged from 0.84 to 0.71 , which shows a satisfactory level of consistency among the items as shown in Table 1. All data analysed and presented in tables/figure was based on the entire data set.

\section{-- Insert Table 1 here --}

We used a confirmatory factor analysis (CFA) using AMOS 18 in order to purify the dimensions of the perceptions of sales as a career path and to predict how these dimensions impact on the likelihood of pursuing a sales career. AMOS is a popular tool to run CFA and structural models and is widely used in the recent marketing literature (e.g., Roy and Rabbanee, 2015). Following Gerbing and Anderson (1988) we adopted a two-step approach to structural equation 
modelling running a measurement model to assess the convergent and discriminant validity prior to estimating the path relationship from a structural model.

In running the measurement model, items with factor loadings lower than 0.40 were deleted. Although a minimum of 0.50 (Hair et al., 2010) standardised factor loading is considered best, it was decided that the cut-off should be at 0.40 in order to cover the broader spectrum of the derived factors. Finally, the structure of the four factors included a total of 15 items with 4 items for 'exciting', 5 items for 'deceptive', 3 items for 'taxing', and 3 items for 'challenging'. The measurement model revealed satisfactory goodness of fit indices $\left(\chi^{2}=222.98 ; \mathrm{df}=84, \chi^{2} / \mathrm{df}=2.65\right.$, $\mathrm{RMSEA}=0.061, \mathrm{CFI}=0.92, \mathrm{NFI}=0.90 ; \mathrm{TLI}=0.88)$. Convergent validity was tested by checking the substantial factor loading of all items (Hair et al., 1995; Raimondo et al., 2008) which significantly loaded onto the expected latent construct at the 0.01 level (see Table 2).

\section{-- Insert Table 2 here --}

The average variance extracted (AVE) for each of the four derived constructs was calculated and shows that the AVE of each construct was greater than 0.50. This supported convergent validity of the constructs of interest (Fornell and Larcker, 1981). The square root of AVE of a given construct was greater than the absolute value of the standardized correlation of the given construct with any other construct/variable as shown in Table 3, which supports convergent and discriminant validity (Fornell and Larcker, 1981; Bagozzi and Yi, 1988).

\section{-- Insert Table 3 about here -}

Correlation values between the constructs - 'exciting', 'deceptive', 'taxing', and 'challenging' were within the acceptable limit that supported discriminant validity of the constructs (Kline, 2005). In order to ensure the internal consistency of the constructs, the construct reliability 
(CR) was calculated for each construct. The lowest construct reliability was found to be 0.80 (for the factor 'challenging') which supports adequate internal consistency of the constructs.

AMOS was run to determine the structural path relationships (see Figure 1). The fit indices of the structural model revealed an acceptable fit with the data $(\chi 2=232.45 ; \mathrm{df}=95 ; \chi 2 / \mathrm{df}=2.44$; RMSEA $=.058 ; \mathrm{CFI}=.92 ; \mathrm{TLI}=.90 ; \mathrm{NFI}=.88)$. The structural path relationships and the corresponding coefficients are shown in the Table 4.

\section{-- Insert Figure 1 here -- \\ -- Insert Table 4 here --}

Table 4 shows that of the four factors, only one factor - 'exciting' was found to have significant impact on the 'likelihood of pursuing a sales career' with a beta value 0.44 . This suggests that students are more likely to pursue a sales career because they consider it to be 'exciting'. On the other hand, the non-significant results for other factors: 'deceptive', 'taxing', and 'challenging' connote that students' perception about sales is not a significant issue to consider.

\section{Cultural background and sales as an 'exciting' career}

Students' perception towards sales as an exciting career was examined based on their cultural background, which was operationalized based on students' country of birth. An independent samples t-test was run taking each of the four items of the factor 'exciting' as the dependent variable and country of birth as the independent variable. Australian born students' perception towards sales was compared with Asian born students' to explore whether any contrast exists in the perception of sales as an exciting career between Australian and Asian students. In order to calculate the number of Asian students, we included students from Malaysia, Indonesia, Singapore, 
Mainland China, Hong Kong and Thailand (we excluded Mauritius students as Mauritius belong to the continent of Africa). The t-test results are shown in Table 5.

\section{-- Insert Table 5 here --}

Table 5 shows that students' perceptions towards sales as an 'innovative', 'exciting' and a 'fun' career vary between Australian-born and Asian-born students as the t-values for these items were found to be significant. One the other hand, the t-value for 'interesting' was not found to be significant; hence students' perception towards sales as an 'interesting' career does not vary across cultures. Interestingly, the mean scores for Asian students were significantly higher than that for Australian students in all of the items. This indicates that Asian born students (i.e. students of collective culture) perceive sales as more 'innovative', 'exciting' and 'fun' than the Australian born students (i.e. students' of individualistic culture).

\section{Discussion}

Firms are devoting substantial efforts to position and/or reposition their sales forces. Institutions for higher education are increasing their specialised courses on 'personal selling' and 'sales management'. However, the question remains unanswered as to whether prevailing stereotypical negative views toward sales as a career has changed in recent times. In this light, this study explores Australasian students' perception towards sales as a career and reveals that Australasian students are willing to pursue a sales career because they view a sales career as being 'exciting'. The study further reveals that the majority of the respondents do not view sales in a negative way, as none of the negatively connoted factors ('deceptive', 'taxing', and 'challenging') were found to have significant impact on the likelihood of pursuing sales as a career. 
The results emanating from this cross-national study differ from research undertaken by Bristow et al. (2006) who found that scepticism of sales as a career continues to exist even among students who had taken a sales course. Our findings also differ from the research findings of Barat and Spillan (2009: p. 57) whose findings "reinforce the negative perception that students in general, harbour towards salespeople and/or a sales career”. Our finding that students' perceptions towards a sales career are seen as 'exciting' is more likely due to the positive influence of a university education that includes Sales Management as a core unit within its curriculum (Baalbaki et al., 2014; Concha et al., 2014; Baalbek et al., 2014). Sales management is therefore considered essential to students pursuing studies in marketing, given that a large percentage of new graduates will commence their careers in some level of sales. All participants in this study completed the Sales Management unit.

We further suggest that this positive view of sales as a career emanates from specific sales skills taught within the core unit of Sales Management. Such skills help to diffuse the negative views of sales that prevail, and assist in educating students that a career in sales can be rewarding in terms of both intrinsic and extrinsic manner. This view is supported by existing literature (e.g. Baalbaki et al. 2014). Within the Sales Management unit, specific sales skills are taught by long term sales professionals who, in addition to their academic qualifications, have extensive sales experience spanning a variety of professional selling organisations both in Australia and overseas. These industry /academic professionals engage students in work integrated (experiential hands on) learning (Mich et al., 2011). This goes some way to solve the problem raised by Loe and Inks (2014) regarding lecturers who teach advanced selling courses and who lack guidance.

Additionally, as a requirement of the Sales Management unit, students meet with industry sales professionals from a variety of sales organisations, (Leasher and Moberg, 2008) where they 
discuss various aspects of sales, preparing them to be work ready (West, 2006; Butler, 2012). This is in line with Lagace and Longfellow (1989) who found industry interaction improves student attitudes toward sales rather than lecture-style sales courses (Baalbaki et al., 2014; Knights et al., 2014). When back on campus, students are actively engaged in exercises, role plays (Rocco and Whalen, 2014; Newberry and Collins, 2012; Sojka and Fish, 2008), and presentations. Cummins et al. (2015) suggest that using experienced salespeople to present classroom materials was very effective.

Moreover, students watch DVDs on different sales activities and other experiential methods (Baalbaki et al., 2014; Barat and Spillan, 2009). These activities are then compared with the interaction that they receive from visiting the professional selling organisations. Thus the university education is playing a key role in shifting the existing stereotypical negative views toward sales by offering different specialized sales related courses at under-graduate level. This view is supported by existing research (Bristow et al., 2006), who report a positive correlation between curricular exposure to sales and student interest pursuing a sales career. Amin et al. (1995) states that students not exposed to sales in academia have traditionally shown a negative attitude toward sales career. Sojka et al. (2000) also supports that educators can accurately reflect the attributes, challenges and opportunities of a selling position and can exert a stronger influence on students' consideration of sales as a preferred career. This view is not just limited to sales, as students from other disciplines (such as accounting) also affirm that a major influence on career decisions emanated from the academic community (Kuzma et al., 2009; Jackling and Calero, 2006). Therefore, considerable research has confirmed that the instructor is one of the key factors that shape students' attitudes towards a career (Concha et al., 2014; Curran and Rosen, 2006). 
The study reveals that Asian students view a sales career as more exciting, innovative and fun than Australian students as the mean scores for Asian students were found to be significantly higher than that for Australian students for the scale items of 'innovative', 'exciting' and 'fun'. This result is found to be counter-intuitive as Australia is considered to be more individualistic that Asian countries. Our finding is supported by Karakaya et al. (2011), who through a cross-cultural study, found that the mean score (3.37) of likelihood of pursuing a professional sales career for Turkish respondents (primarily collectivist society) was higher than the mean score of respondents from the U.S. (3.20) and Switzerland (3.18). Notably, both the U.S. and Switzerland are considered as being more individualistic societies than Turkey.

Our finding shows that the positive perception of sales as a career path is similar across countries. As evident from the diverse countries of birth of our respondents, where $35.5 \%$ are from Malaysia, $16.7 \%$ are from Australia with the remainder (47.8\%) from numerous other countries such as Indonesia, Singapore, Mainland China, Hong Kong, and Thailand. Thus, by being crossnational, this study addresses one of the key limitations of Bristow et al. (2006), whose findings lacked generalizability due to lack of ethnic diversity in the sample. This study further revealed that there is no significant difference between male and female students' perceptions towards a sales career. This is an important finding because both males and females essentially believe that the sales profession is 'exciting'. The findings of this study are supported by Belizza and Hasty (2001) who examined the effects of gender on managerial response to salespersons' ethical decisions; and suggested that if differences exist between male and female decisions, they are related to the specific situation and individual characteristics rather than gender. This is in line with Potrafke (2015), who mentioned that the consequences of globalization has promoted gender equality. 


\section{Implications}

This study offers significant theoretical and managerial implications. It extends the extant sales literature in the following ways. Firstly, the study reveals that students view sales as an 'exciting' career as opposed to past stereotypical negative impression toward a sales career. Secondly, it reveals that the perception of sales as an 'exciting' career is similar across culture and gender. Thirdly, it addresses one of the key limitations of et al. (2006) whose findings lacked generalizability due to lack of ethnic diversity in the sample, suggesting the use of multiple locations to capture a diverse cultural mix of respondents within the homogeneous student cohort. This view is supported by Fournier et al. (2014) who advise that the empirical research that exists in the sales literature is mostly based on a single-country sample. Fourth, this study identifies a four factor model of influencing students' perception towards a sales career. The identified factors are novel, psychometrically sound, and thus extend existing sales literature. Finally, this study indicates that Asian born students perceive sales as more 'innovative', 'exciting' and 'fun' than the Australian born students.

This study offers significant implications for sales and marketing practitioners. Its findings indicate that students' perception towards a sales career have changed in recent times. Students now view a sales career as being 'exciting', which is supported by the satisfying factor of the Herzberg's two factor model of motivation. It is directly related to the job content and contributes to personal fulfilment. This is in line with our previous discussion that students of $21^{\text {st }}$ century intend to pursue a sales career due to the inherent nature of the sales job that contributes to achievement, personal development and fulfilment.

The perception of sales as an 'exciting' career is of particular interest to sales and marketing managers as well as to recruiters (Bahhouth et al., 2011). Sales managers and recruiters need to be 
aware of the key attributes of a sales career (Rahman et al., 2014; Waldeck et al., 2010) and the perceptions of the incumbents (Sohail, 2004), which will help them to develop and implement an effective sales force plan. Given the high cost associated with recruitment, selection and training of the sales force and the negative consequences of selecting the wrong person for a sales position, the findings of this study will help sales managers and recruiters in crafting effective advertisements for sales positions and selecting the right people; those who perceive sales as being exciting and fun. For example sales careers could be promoted by emphasizing the positive aspects of a sales position i.e. exciting, salesperson's value to society, sales ethics (Cummins et al., 2015), flexibility and work life balance (Sojka et al. 2000), thereby encouraging students to pursue a sales career (Sohail, 2004; Cummins et al., 2016).

In addition, findings of this study are extremely relevant to the Australian higher education sector. Australia is a multi-cultural society with major trading partners in South East Asia. This is reflected in the high percentage of South East Asian students pursuing their undergraduate studies in Australian universities. However, many business graduates lack practical skills (Stringfellow et $a l ., 2006)$ and a lack of understanding of the requirements of today's sales professionals, which can be attributed to students' lack of willingness to pursue sales careers. Hence, the identification of 'perceptual factors' that influence the choice of a sales career is critical for both students and businesses.

From recruitment perspective, if sales force recruiters understand the perceptions of students regarding sales as a career, they will be more likely to discuss those relevant factors with potential candidates. Therefore, understanding the perceptions that students have about a sales career enables employers to target those specific requirements and discuss them with prospective employees during interviews (Lee et al., 2007). Findings of this study indicate interrelationships between 
education and industry in developing positive attitudes towards sales careers by creating an industry-academia interface for an increased industry-academia connectedness. This view is supported by Cummins et al. (2016) whose research showed that educational intervention positively impacted students' perceptions of a sales career. This is because, academic staff of a university act as 'change agents' who are in the position of encouraging students' attitudes and perceptions toward a sales career (Pettijohn and Pettijohn, 2009). As a result graduating students become interested in a sales career and feel interested to stay longer in the sales jobs once they secure a position. This in turn will contribute to reducing employee turnover and thus save costs for the firm.

Our finding that Asian students perceive sales as more 'innovative', 'exciting' and 'fun' than Australian students has significant implications for sales managers and recruiters, who have been paying attention to diversifying their sales force (DelVecchio and Honeycutt, 2000). Although prior research has focused on students' attitudes towards a sales career, only a few of these studies specifically relate to the ethnicity of students (Fournier et al., 2014). As multicultural countries like Australia have large migrant populations, companies will increasingly feel the need to attract sales people from diverse ethnic backgrounds. This is relevant for global and/or multinational firms who market products and brands across the world (Paul, 2015). Thus our findings offer empirical evidence that will help marketing practitioners in selecting sales persons from diverse ethnic background and those who view sales careers as being innovative and exciting (Fournier et al., 2014).

\section{Limitations and Future Research Directions}

As with all other research, our study has limitations. First, despite the fact that this study is a cross national study where five different countries namely Australia, Singapore, Hong Kong, Malaysia and Mauritius were involved, the research was primarily under the control of one university. 
Accordingly the perception towards a sales career could have been different if the data were collected from independent universities and/or other countries. Second, significant difference was noted between Australian and Asian students' perceptions towards sales as an exciting, innovative and fun career. Since Asia is the largest continent with different cultures, religions and races, it is prudent to interpret and generalize our finding with caution. Third, as we measured intention to pursue a sales career through a single item measure, future research could consider measuring intention to pursue a sales career using multi-item measures. Fourth, whilst this study uses a purposive sample of a student cohort to reveal the significance of the 'excitement' that a sales career generates, more rigorous sampling techniques could be adopted in future research in order to explore the attitudes towards a sales career. Fifth, although no statistically significant differences were noted between genders in terms of perceptions of a sales career, the significant differences between Australian and Asian-born students suggest an in-depth study on these groups. Sixth, future research can focus on the cross-cultural examination based on the Hofstede (1980)'s different cultural dimensions in order explore whether the cultural dimensions have any moderating influence in relationship between the factors influencing a sales career and intention to pursue a sales career. Seventh, this study is exploratory in nature and the factors influencing students' perception toward a sales career were developed based on the finding derived from exploratory factor analysis. Although we confirmed the scale items of the four factors using confirmatory factor analysis, yet more robust scale development procedure can be adopted to offer the scale items for factors relating to perception of a sales career. Eighth, we collected data regarding the factors influencing students' intention to pursue a sales career from both Australian and Asian born students across multiple campuses of the university located in different countries. Future study may focus on conducting a comparative study covering multiple countries and test the model using the multi country data with more methodological rigour. Finally, future investigation could apply pre and post examination of 
the perceptions of students who enrol in a sales management unit by asking them at the beginning of the semester and at the end when they have completed the sales course. This would lead to determine whether their perceptions of a sales career shifts after they have been exposed to the course as opposed to the beginning when they had no prior theoretical understanding of what Sales Management entails. 


\section{References}

Agnihotril, R., Bonney, L. Dixon, A. Erffmeyer, R. Pullins, E. Sojka, J. and West, V. (2014), "Developing a Stakeholder Approach for Recruiting Top-Level Sales Students", Journal of Marketing Education, Vol. 36 No. 1, pp. 75-86.

Amin, S.G., Hayajneh, A.F. and Nwakanma, H. (1995), "College students' views of sales jobs as a career: an empirical investigation”, American Business Review, Vol. 13 No. 2, pp. 54-60.

Anderson, R.E., Dixon, A.L., Jones, E., Johnston, M.K., LaForge, R.W., Marshall, G.W., and Tanner, J.F. (2005). "The scholarship of teaching in sales education", Marketing Education Review, Vol. 15 No. 2, pp.1-10.

Baalbaki, S., Black, G.S., Lee, J.D. and Sherwood, S.G. (2014), “Attitudes, opinions, and characteristics: creating a profile of sales students", American Journal of Business Management, Vol. 3 No. 3, pp. 130-142.

Bagozzi, R.P., Belschak, F. and Verbeke, W. (2010), "The role of emotional wisdom in salesperson's relationships with colleagues and customers", Psychology and Marketing, Vol. 27 No. 11, pp. 1001-1031.

Bagozzi, R.P. and Yi, Y. (1988), "On the evaluation of structural equation models", Journal of the Academy of Marketing Science, Vol. 16 No. 1, pp. 74-94.

Bahhouth, V., Spillan, J.E. and Józefowski, B. (2011), "Predictive power of personal factors in studying students' perception of sales profession in Poland", Journal of East-West Business, Vol. 17 No 4, pp. 195-212.

Bahhouth, V., Spillan, J. and Karsaklian, E. (2014), “Are students driven by negative or positive perception about sales profession in France?" European Journal of Business and Social Sciences, Vol. 3 No.1, pp 16-32

Bahhouth, V., Spillan, J., Maysami, R. and Liang, L. (2014), "Does the personal trait play a significant role on Chinese students' perception of sales profession as a career?"

International Journal of Humanities and Social Science, Vol. 4 No. 1, pp. 29 - 37.

Bahhouth, V., Spillan, J. and Mensah, E. (2013), "Predictive power of personal factors in studying students' perception of sales profession in Ghana", International Journal of Business and Social Science, Vol. 4 No. 7, pp. 291-296.

Barat, S. and Spillan, J.E. (2009). “A cross country comparative analysis of students' perceptions of the sales profession: a look at U.S., Peru, and Guatemala”, Marketing Management Journal, Vol. 19 No. 2, pp. 52-63.

Barr, T.F. and McNeilly, K.M. (2002), “The value of students' classroom experiences from the eyes of the recruiter: information, implications and recommendations for marketing educators", Journal of Marketing Education, Vol. 24 No. 2, pp. 168-173. 
Bellizza, J.A. and Hasty, R.W. (2001), "The effects of a stated organisational policy on inconsistent disciplinary action based on salesperson gender and weight", Journal of Personal Selling and Sales Management, Vol. 21 No. 3, pp. 189-198.

Blythe, J. (2005), Sales and key account management, Thomson Learning, London.

Bolander,W., Bonney, L. and Satornino, C. (2014), "Sales education efficacy: examining the relationship between sales education and sales success", Journal of Marketing Education, Vol. 36 No. 2, pp. 169-181.

Bristow, D.N., Amyx, D., Castleberry, S.B. and Cochran, J.J. (2011), “A cross-generational comparison of motivational factors in a sales career among Gen-X and Gen-Y college Students", Journal of Personal Selling \& Sales Management, Vol. 31 No. 1, pp. 77-85.

Bristow, D.N., Amyx, D. and Slack, J. (2006), “An empirical look at professional selling from a student perspective", Journal of Education for Business, Vol. 81 No. 5, pp. 242-249.

Bristow, D.N. and Gulati, R. (2002), "The teaching of sales related courses at the university level: an empirical look from the sales manager's perspective", Journal of Selling and Major Account Management, Vol. 4 No. 3, pp. 25-43.

Bristow, D.N., Gulati, R. and Amyx, D. (2006), “A look at professional selling from the students' perspective: a replication and extension”, Marketing Management Journal, Vol. 16 No. 1, pp. 88-103.

Burnett, M., Pettijohn, C. and Keith, N. (2008), "A comparison of the ethical perceptions of prospective personal selling and advertising employees", Marketing Management Journal, Vol. 18 No. 1, pp. 77-83.

Bush, A., Bush, V., Oakley, J. and Cicala, J. (2014), "F.ormulating undergraduate student expectations for better career development in sales: a socialization perspective", Journal of Marketing Education, Vol. 36 No. 2, 120-131

Butaney, G. T. (2007), "A commentary on 'undergraduate education: the implications of crossfunctional relationships in business marketing -the skills of high-performing managers", Journal of Business-to-Business Marketing, Vol. 14 No. 1, pp. 103-109.

Butler, D.D. (2012). “Take a professional to lunch: A process to establish a professional network", Marketing Education Review, Vol. 22 No. 1, pp. 39-40.

Caballero, R. and Joonas, K. (2009), “Mexican students' attitudes towards personal selling: an exploratory investigation”, AIMS International, Vol 3 No. 3, pp. 221-240.

Carless, S.A. (2005), "Person-job fit versus person-organization fit as predictors of organizational attraction and job acceptance intentions: a longitudinal study", Journal of Occupational and Organizational Psychology, Vol. 78 No. 3, pp. 411-429. 
Chatman, J.A. (1991), "Matching people and organizations: selection and socialization in public accounting firms", Administrative Science Quarterly, Vol. 36 No. 3, pp. 459-484.

Claar, V.V., TenHaken, V.R. and Frey, R. (2009), "Entrepreneurial attitudes of MBA students in the United States relative to the CIS: the case of Armenia", International Business \& Economics Research Journal, Vol. 8 No. 2, p. 67-76.

Collins, M.K., Newberry, R. and Tyler, L. (2012), "Recruiting recent graduates for entry level sales positions: aligning message and media with student expectations", Journal of Business and Behavioural Sciences, Vol. 24 No 3, pp. 148-160.

Concha, A., Kumar, P.; Tarasil, C. and Wilson, H. (2014), "Selling sales factors influencing undergraduate business students' decision to pursue sales education", Journal of Marketing Education, Vol. 36 No. 2, pp. 94 -104.

Cummins,S.W.; Peltier, J.W.; Pomirleanu, N.; Cross, J. and Simon, R. (2015), "Evaluating educational practices for positively affecting student perceptions of a sales career", Journal of Marketing Education, Vol. 37 No. 1, pp. 25-35.

Cummins, S., Loe, T. and Peltier, J.W. (2016), "Using sales competition videos in a principles of marketing class to improve interest in a sales career", Journal of Advancement of Marketing Education, Vol. 24 special issue, pp. 16.21.

Curran, J.M. and Rosen, D.E. (2006), "Student attitudes toward college courses: an examination of influences and intentions", Journal of Marketing Education, Vol. 28 No. 2, pp. 135-148.

Dawis, R.V. and Lofquist, L.H. (1984), A Psychological Theory of Work Adjustment: An Individual-Differences Model and Its Applications, University of Minnesota Press, Minneapolis.

DeCarlo, T.E., Rody, R.C. and DeCarlo, J.E. (1999), “A cross national example of supervisory management practices in the sales force", Journal of Personal Selling and Sales Management, Vol. 19 No. 1, pp. 1-14.

Deeter-Schmelz, D.R., and Kennedy, K.N. (2011), “A global perspective on the current state of sales education in the college curriculum", Journal of Personal Selling and Sales Management, Vol. 31 No. 1, pp. 55-76.

DelVecchio, S. and Honeycutt, Jr. (2002), "Explaining the appeal of sales careers: a comparison of black and white college students", Journal of Marketing Education, Vol. 24 No. 1, pp. 56-63.

DelVecchio, S., and Honeycutt, E.D. (2000), “An investigation of African-American perceptions of sales careers”, Journal of Personal Selling and Sales Management Vol. 20 No. 1, pp. 43-52. 
Dixon, A.L. and Tanner, J. F. (2012), "Transforming selling: why it is time to think differently about sales research", Journal of Personal Selling \& Sales Management, Vol. 32 No. 1, pp. 9-13.

Donavan, T.D., Brown, T.J. and Mowen, J.C. (2004), "Internal benefits of service-worker customer satisfaction, commitment, and organizational citizenship behaviours", Journal of Marketing, Vol. 68 No.1, pp. 128-146.

Dubinsky, A.J. (1980), "Recruiting college students for the sales force”, Industrial Marketing Management, Vol. 9 No. 1, pp. 37-45.

Duke, C.R. (2002), "Learning outcomes: comparing student perceptions of skill level and importance", Journal of Marketing Education, Vol. 24 No. 3, pp. 203-217.

Dwyer, S., Orlando, R. and Shepherd, C.D. (1998), “An exploratory study of gender and age matching in the salesperson-prospective customer dyad: testing similarity-performance predictions", Journal of Personal Selling and Sales Management, Vol. 18 No. 4, pp. 5569.

Eldridge, R. (2008), "Getting wise to the ways of the Ys . . or Not", Personnel Today, September 16 , p. 18.

Fogel, S., Hoffmeister, R.R. and Strunk, D.P. (2012), “Teaching sales”, Harvard Business Review, Vol. 90 No. 7, pp. 94 - 99.

Fournier, C.; Cheron, E.; Tanner, J.F.; Bikanda, P.J. and Wise, J.A. (2014), "A cross-cultural investigation of the stereotype for salespeople: professionalizing the profession", Journal of Marketing Education, Vol. 36 No. 2, pp. 132-143.

Fornell, C. and Larcker, D.F. (1981), "Structural equation models with unobservable variables and measurement error: algebra and statistics", Journal of Marketing Research, Vol. 17 No. 3, 382-388.

Frese, M., Fay, D., Hilburger, T., Leng, K. and Tag, A. (1997), "The concept of personal initiative: operationalization, reliability and validity in two German samples", Journal of Occupational and Organisational Psychology, Vol. 70 No. 2, pp. 139-161.

Galea, C. (2005), "In high demand”, Sales and Marketing Management, Vol. 15 June, p. 9.

Gerbing, D.W. and Anderson, J.C. (1988), “An updated paradigm for scale development incorporating uni-dimensionality and its assessment", Journal of Marketing Research, Vol. 25 No. 2, 186-192.

Gong, W. (2003), "Chinese consumer behaviour: a cultural framework and implementations", Journal of the American Academy of Business, Vol. 3 No. 1/2, pp. 373-384.

Gray, D.M., Peltier, J.W. and Schibrowsky, J.A. (2012), "The journal of marketing education: past, present, and future", Journal of Marketing Education, Vol. 34 No. 3, pp. 217-237. 
Hair, J.F., Anderson, R.E., Babin, B.J. and Mehta, R. (2009), Sales Management: Building Customer Relationships and Partnerships, Houghton Mifflin, NY.

Hair, J.F., Black, W.C., Babin, B.J. and Anderson, R.E. (2010), Multivariate Data Analysis: A Global Perspective, 7th ed., Pearson Education, Inc., NJ.

Hartman, K.B. (2006), "Television and movie representations of salespeople: beyond Willie Loman”, Journal of Personal Selling and Sales Management, Vol. 26 No. 3, pp. 293-292.

Hawes, J.M., Rich, A.K. and Widmier, S.M. (2004), "Assessing the development of the sales profession”, Journal of Personal Selling and Sales Management, Vol. 24 No. 1, pp. 2737.

Healy, W.J., Taran, Z. and Betts, S.C. (2011), "Sales course design using experiential learning principles and Bloom's taxonomy”, Journal of Instructional Pedagogies, Vol. 6 No. 1, pp. $1-10$.

Herche, J., Swenson, M.J. and Verbeke, W. (1996), "Personal selling constructs and measures: emic versus etic approaches to cross-national research", European Journal of Marketing, Vol. 30 No. 7, pp. 83-97.

Herzberg, F. (1966), Work and the Nature of Man, World, Cleveland.

Hofstede, G. (1980), Cultures consequences: International differences in work-related values, Sage, Beverley Hills, CA.

Holland, J.L. (1997), Making Vocational Choices: A Theory of Vocational Personalities and Work Environments, 3rd ed., Psychological Assessment Resources, Odessa, FL.

Honeycutt, E.D., and Ford, J.B. (1995), "Guidelines for managing an international sales force," Industrial Marketing Management, Vol. 24 No. 2, pp. 135-144.

Honeycutt, E.D., Ford, J.B., Swenson, M.J. and Swinyard, W. (1999), "Student preferences for sales careers around the Pacific-Rim”, Industrial Marketing Management, Vol. 28 No. 1, pp. 27-36.

Honeycutt, E.D. and Thelen, S. (2003), "Education, attitudes, and career intent in the Philippines", Marketing Education Review, Vol. 13 No.3, pp. 65-72.

Jackling, B. and Calero, C. (2006), "Influences on undergraduate students' intentions to become qualified accountants: evidence from Australia", Accounting Education: an International Journal, Vol. 15 No. 4, pp. 419-438.

James, W.L. and Sonner, B.S. (2001), "Just say no to traditional student samples", Journal of Advertising Research, Vol. 41 No. 5, pp. 63-71.

Karakaya, F., Quigley, C. and Bingham, F. (2011), “A cross-national investigation of student intentions to pursue a sales career", Journal of Marketing Education, Vol. 33 No. 1, pp. $18-27$. 
Kavas, A. (2003), “African-American students' attitudes toward personal selling as a career”, Negro Educational Review, Vol. 54 No. 1-2, pp. 31-38.

Kelan, E. (2008), “Generational and gender transformations”, Personnel Today, September 16, 38 39.

Kerin, R.A., Hartley, S.W. and Rudelius, W. (2009), Marketing, 9th ed., McGraw-Hill Irwin, Boston, MA.

Klein, T.A., Laczniak, G.R. and Murphy, P.E. (2006), "Ethical marketing: a look on the bright side”, Marketing Management Journal, Vol. 16 No. 1, pp. 228-243.

Kline, R.B. (2005), Principles and Practices of Structural Equation Modelling, $2^{\text {nd }}$ ed., Guildford Press, NY.

Knights, P, Mich, C.C. and Manion, M.T. (2014). The role of self-efficacy in sales education, Journal of Marketing Education, Vol. 36 No. 2, pp. 156-168.

Kuzma, A.T., Kuzma, J.R. and Thiewes, H.F. (2009), "Students' expectations of a career in Sales: a comparison of finance and marketing majors", American Journal of Business Education (AJBE), Vol 2 No. 5, pp. 45-52.

Lagace, R.R. and Longfellow, T.A. (1989), “The impact of class- room style on student attitudes toward sales careers: a comparative approach", Journal of Marketing Education, Vol. 11 No. 3, pp. 72-77.

Lassk, F.G., Ingra, T.N., Kraus, F. and DiMascio, R. (2012), "The future of sales training: challenges and related research questions", Journal of Personal Selling and Sales Management, Vol. 32 No. 1, pp. 141-154.

Leasher, M.K., and Moberg, C.R. (2008), "Evaluating the impact of collegiate sales training and education on early salesperson performance", Journal of Selling and Major Account Management, Vol. 8 No. 4, pp. 32-45.

Lee, N., Beatson, A., Garrett, T.C., Lings, I. and Zhang X. (2009), “A study of the attitudes towards unethical selling amongst Chinese salespeople", Journal of Business Ethics, Vol. 88, No. 3 pp. $497-515$

Lee, N., Sandfield, A. and Dhaliwal, B. (2007), "An empirical study of salesperson stereotypes amongst UK students and their implications for recruitment”, Journal of Marketing Management, Vol. 23 No. 7-8, pp. 723-744.

Loe, T. and Inks, S. (2014), "The advanced course in professional selling”, Journal of Marketing Education, Vol. 36 No. 2, pp. 182-196. 
Luthy, M.R. (2000), "Preparing the next generation of industrial sales representatives", Industrial Marketing Management, Vol. 29 No. 3, pp. 235-242.

Lysonski, S. and Durvasula, S. (1998), “A cross-national investigation of student attitudes toward personal selling: implications for marketing education”, Journal of Marketing Education, Vol. 20 No. 2, pp. 161-173.

Mantel, S.P., Pullins, E.B., Reid, D.A. and Buehrer, R.E. (2002), “A realistic sales experience: providing feedback by integrating buying, selling, and managing experiences", Journal of Personal Selling and Sales Management, Vol. 22 No. 1, pp. 33-40.

Marcos-Cuevas, J., Critten, P., Squire, P. and Speakman, J.I.F. (2014), "Enhancing the professional mindset of future sales professionals: key insights from a master in sales transformation", Journal of Marketing Education, Vol.36 No. 2, pp. 144-155

Mason, J.L. (1965), “The low prestige of personal selling”, Journal of Marketing, Vol. 29 No. 4, pp. $7-10$.

McGarty, C., Yzerbyt, V.Y. and Spears, R. (2002), "Social, cultural and cognitive factors in stereotype formation", In McGarty, C., Yzerbyt, V.Y. and Spears, R. (Eds.), Stereotypes as Explanations, 1-15, Cambridge University Press, Cambridge.

McIntyre, F.S. and Tanner, J.F. (2004), "The scholarship of teaching: A study of marketing education journal publications", Marketing Education Review, Vol. 14 No.1, pp. 33-44.

Meglino, B.M., Elizabeth C.R. and Angelo S.D. (2000), "A meta-analytic examination of realistic job preview effectiveness: a test of three counterintuitive propositions", Human Resource Management Review, Vol. 10 No. 4, pp. 407-434.

Mich, C.C., Connors, S.E. and Feldman, L. (2011), "The Impact of experiential learning on sales career adversity", Proceedings of Allied Academies International Conference, Academy of Marketing Studies, Orlando, Vol. 16, No. 1, p. 3-8.

Nachnani, A.G. and Ashok, G. (2007), "Throw out the old playbook: adjusting to the new realities of the sales talent game", Top University Sales Education Programs 2007, A Special Supplement to Selling Power Magazine, (June), 15 and 17.

Neeley, C.R. and Cherry, K.S. (2010), "Zero to 60 in one semester: using an applied advanced selling project to build a professional sales program", Marketing Education Review, Vol. 20 No. 2, pp. 123-130.

Newberry, R. and Collins, M. K. (2012), “A recruiting and hiring role- play: an experiential simulation", Marketing Education Review, Vol. 22 No. 1, pp. 67-72.

Ok, C., Shanklin, C.W. and Back, K. (2008), "Generalizing survey results from student samples: implications from service recovery research", Journal of Quality Assurance in Hospitality and Tourism, Vol. 8 No.4, pp. 1-23. 
Oviedo-Garcia, M.A. (2007), "Internal validation of a bio-data extraversion scale for salespeople", Social Behaviour and Personality: An International Journal, Vol. 35 No. 5, pp. 675-692.

Paul, G.W. and Worthing, P. (1970), “A student assessment of selling”, Southern Journal of Business, Vol. 5, July, pp. 57-65.

Paul, J. (2015), "Market access and the mirage of marketing to the maximum: new measures", Asia Pacific Journal of Marketing and Logistics, Vol. 27 No. 4, pp. 676-688.

Paul, J. and Shrivastava, A. (2015), "Comparing entrepreneurial communities: theory and evidence from a cross-country study in Asia”, Journal of Enterprising Communities: People and Places in the Global Economy, Vol. 9 No. 3, pp. 206-220.

Peltier, J.W., Cummins, S., Pomirleanu, N., Cross, J. and Simon, R. (2014), “A parsimonious instrument for predicting students' intent to pursue a sales career: scale development and validation", Journal of Marketing Education, Vol. 36 No. 1, pp. 62-74.

Pettijohn, C., Pettijohn, L. and Taylor, J.A. (2007), "Does salesperson perception of the importance of sales skills improve sales performance, customer orientation, job satisfaction, and organizational commitment, and reduce turnover?" Journal of Personal Selling and Sales Management, Vol. 27 No. 1, pp. 75-88.

Pettijohn, C. and Pettijohn, L. (2009), “An exploratory analysis of sales career desirability: an MBA perspective", Academy of Educational Leadership Journal, Vol. 13, No. 2, pp. 35-47.

Phillips, J.M. (1998), "Effects of realistic job previews on multiple organizational outcomes: a meta-analysis", Academy of Management Journal, Vol. 41 No. 6, pp. 673-690.

Podsakoff, P.M., Mackenzie, S.B., Lee, J.Y. and Podsakoff N.P. (2003), "Common method biases in behavioral research: a critical review of the literature and recommended remedies. Journal of Applied Psychology, Vol. 88 No 5, 879-903.

Potrafke, N. (2015), “The evidence on globalisation”, The World Economy, Vol. 38 No. 3, pp. 509552.

Roach, D.W., McGaughey, R.E. and Downey, J.P. (2011), "Selecting a business major within the college of business", Administrative Issues Journal: Education, Practice, and Research, Vol. 2 No. 1, pp. 107-121.

Raimondo, M.A., Miceli, G. N. and Costabile, M. (2008), "How relationship age moderates loyalty formation: the increasing effect of relational equity on customer loyalty", Journal of Service Research, Vol. 11 No. 2, pp. 142-160.

Rahman, M.K., Mohamad, M. and Khan, A. (2014), "What motivational factors influence students' interest in sales career? An empirical investigation in Malaysia", IOSR Journal of Business and Management, Vol. 16 No. 3, pp. 73-79. 
Rocco, R.A. and Whalen, D.J. (2014), “Teaching Yes, and ... improve in sales classes: enhancing student adaptive selling skills, sales performance, and teaching evaluations," Journal of Marketing Education, Vol. 36 No. 2, pp. 197-208

Rouzies, D. and Macquin, A. (2003), “An exploratory investigation of the impact of culture on sales force management control systems in Europe", Journal of Personal Selling and Sales Management, Vol. 23 No. 1, pp. 61-72.

Roy, R. and Rabbanee, F.K. (2015), “Antecedents and consequences of self-congruity”, European Journal of Marketing, Vol. 49 No. 3/4, pp. 444-466.

Sears, D.O. (1986), "College sophomores in the laboratory: influences of a narrow data base on social psychology's view of human nature", Journal of Personality and Social Psychology, Vol. 51 No. 3, pp. 515-530.

Sohail, M.S. (2004), 'Influence of ethnicity on students' sales career preference: some observations from a developing multi-racial country", Problems and Perspectives in Management, Vol. 1, pp. 248-256.

Sojka, J.Z. and Fish, M.S.B. (2008), "Brief in-class role plays: an experiential teaching tool targeted to generation Y students", Marketing Education Review, Vol. 18 No. 1, pp. 25-31.

Sojka, J.Z., Gupta, A.K. and Hartman, T.P. (2000), "Student perceptions of sales careers: implications for educators and recruiters", American Journal of Business, Vol. 15 No. 1, pp. 55-64.

Sparks, J.R. and Johlke, M. (1996), "Factors influencing student perceptions of unethical behaviour by personal salespeople: an experimental investigation", Journal of Business Ethics, Vol. 15 No. 8, pp. 871-887.

Spillan, J.E., Totten, J.W. and Chaubey, M.D. (2011), "Exploring personal selling as a career option: a case study of the perceptions of African-American students", Academy of Marketing Studies Journal, Vol. 15 No. 2, pp. 93-106.

Stephens, G.K. and Greer, C.R. (1995), "Doing business in Mexico: understanding cultural differences”, Organizational Dynamics, Vol. 24 No. 1, pp. 39-55.

Stern, B.L. and Tseng, L.P.D. (2002), "Do academics and practitioners agree on what and how to teach the undergraduate marketing research course?" Journal of Marketing Education, Vol. 24 No. 3, pp. 225-232.

Stevens, C D. and Macintosh, G. (2003), "Personality and attractiveness of activities within sales jobs", Journal of Personal Selling and Sales Management, Vol. 23 No. 1, pp. 23-37.

Stewart, T.A. (2006), “The top Line”, Harvard Business Review, Vol. 84 No. 7/8, p. 10.

Stringfellow, L., Ennis, S., Brennan, R. and Harker, M.J. (2006), "Mind the gap: the relevance 
of marketing education to marketing practice", Marketing Intelligence \& Planning, Vol. 26

No. 3, pp. 245-256.

Sweeney, J. and Soutar, G. (2001), "Consumer perceived value: the development of a multi item scale”, Journal of Retailing, Vol. 77 No. 2, pp. 203- 220.

Tanner, J.F.Jr., Fournier, C., Wise, J.A., Hollet, S. and Poujol, J. (2008), “Executive’s perspectives of the changing role of the sales profession: views from France, the United States, and Mexico", Journal of Business and Industrial Marketing, Vol. 23 No. 3, pp. 193202.

Waldeck, N,E., Pullins E, B. and Houlette, M. (2010), "Media as factor in student perceptions for sales jobs: a framework for research", Journal of Personal Selling \& Sales Management, Vol. 30 No. 4, pp. 343-353.

Walker, I., Tsarenko, Y., Wagstaff, P., Powell, I., Steel, M. and Brace-Govan, J. (2009), “The development of competent marketing professionals", Journal of Marketing Education, Vol.31 No. 3, pp. 253-263.

Webster, C. and Sundram, D. (1998), "Service consumption criticality in failure recovery", Journal of Business Research, Vol. 41 No. 2, pp. 153-159.

Weilbaker, D.C. and Williams, M. (2006), "Recruiting new sales- people from universities: university sales centres offer a better alternative", Journal of Selling and Major Account Management, Vol. 6 No. 3, pp. 30-38.

West, V.L. (2006), "Teaching written communication skills in professional selling: the cover letter", Journal of Marketing Education, Vol. 28 No. 3, pp. 205217.

Wiles, M.A. and Spiro, R.L. (2004), “Attracting graduates to sales positions and the role of recruiter knowledge: a re-examination", Journal of Personal Selling and Sales Management, Vol. 24 No. 1, pp. 493-498.

Yoon, C., Hasher, L., Feinberg, F., Rahhal, T.A. and Winocur, G. (2000), "Cross-cultural differences in memory: the role of culture-based stereotypes about aging", Psychology and Aging, Vol. 15 No. 4, pp. 694-704. 


\section{APPENDICES}

Table 1: Rotated component matrix

\begin{tabular}{|c|c|c|c|c|}
\hline \multirow[b]{2}{*}{ Variables } & \multicolumn{4}{|c|}{ Factors } \\
\hline & $\begin{array}{c}1 . \\
\text { Exciting }\end{array}$ & $\begin{array}{c}2 . \\
\text { Deceptive }\end{array}$ & $\begin{array}{c}3 . \\
\text { Taxing }\end{array}$ & $\begin{array}{c}4 . \\
\text { Challenging }\end{array}$ \\
\hline $\begin{array}{l}\text { Exciting } \\
\text { Fun } \\
\text { Interesting } \\
\text { Make money } \\
\text { Rewarding } \\
\text { Innovative } \\
\text { Require discipline } \\
\text { Involve Public Relations } \\
\text { Involve travel } \\
\text { Require patience } \\
\end{array}$ & $\begin{array}{l}.792 \\
.750 \\
.671 \\
.608 \\
.596 \\
.568 \\
.545 \\
.502 \\
.440 \\
.426 \\
\end{array}$ & & & \\
\hline $\begin{array}{l}\text { Involve lying } \\
\text { Limited } \\
\text { Unappealing } \\
\text { Pushy } \\
\text { Involve deception } \\
\text { Boring } \\
\text { Repetitious } \\
\text { Frustrating } \\
\end{array}$ & & $\begin{array}{l}.697 \\
.681 \\
.636 \\
.617 \\
.596 \\
.558 \\
.547 \\
.448 \\
\end{array}$ & & \\
\hline $\begin{array}{l}\text { Taxing } \\
\text { Involve pressure } \\
\text { Time consuming } \\
\text { Involve risk } \\
\text { Stressful } \\
\text { Require dedication } \\
\end{array}$ & & & $\begin{array}{l}.748 \\
.721 \\
.681 \\
.584 \\
.542 \\
.419 \\
\end{array}$ & \\
\hline $\begin{array}{l}\text { Competitive } \\
\text { Challenging } \\
\text { Hard } \\
\text { Hard work } \\
\text { Exhausting } \\
\text { Require persuasion } \\
\end{array}$ & & & & $\begin{array}{l}.586 \\
.580 \\
.512 \\
.496 \\
.475 \\
.435 \\
\end{array}$ \\
\hline $\begin{array}{l}\text { Eigen Value } \\
\% \text { of Variance } \\
\text { Cronbach's Alpha }\end{array}$ & $\begin{array}{c}7.12 \\
20.93 \\
.84\end{array}$ & $\begin{array}{c}4.88 \\
14.34 \\
.80\end{array}$ & $\begin{array}{l}1.76 \\
5.18 \\
.79\end{array}$ & $\begin{array}{l}1.52 \\
4.46 \\
.71\end{array}$ \\
\hline
\end{tabular}

Extraction: Varimax rotation with Kaiser normalisation $\mathrm{KMO}=.887 ; \alpha=.903$ 
Table 2 - Factor loading and descriptive statistics of the items of the constructs

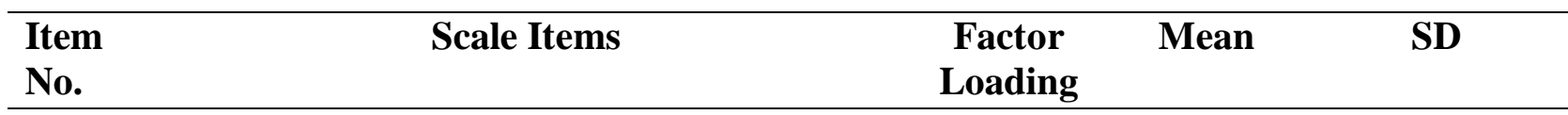

Exciting [Construct reliability $=0.85$ ]

Fl.1 A sales job is likely to be interesting.

Fl.2 A sales job is likely to be innovative

.63

5.34

1.14

.48

5.46

1.10

Fl.3 A sales job is likely to be exciting

.87

5.37

1.23

Fl.4 A sales job is likely to be fun.

.75

5.12

1.27

Deceptive [Construct reliability $=0.85$ ]

F2.1 A sales job is likely to be boring.

.74

3.33

1.50

F2.2 A sales job is likely to involve deception.

.64

4.32

1.45

F2.3 A sales job is likely to be pushy.

.66

4.56

1.41

F2.4 A sales job is likely to be limited.

.49

3.89

1.41

F2.5 A sales job is likely to involve lying.

.71

3.72

1.63

Taxing [Construct reliability $=0.85$ ]

F3.1 A sales job is likely to involve pressure.

.75

5.46

1.20

F3.2 A sales job is likely to be taxing.

.72

4.74

1.32

F3.3 A sales job is likely to be time consuming.

.73

5.30

1.21

Challenging [Construct reliability $=0.80$ ]

F4.1 A sales job is likely to be competitive.

.74

5.90

1.00

F4.2 A sales job is likely to challenging.

.79

5.86

0.91

F4.3 A sales job is likely to require persuasion.

.48

5.66

1.13 
Table 3 - AVE and Correlations

\begin{tabular}{llllll}
\hline Constructs & AVE & F1 & F2 & F3 & F4 \\
\hline Factor 1 (F1: Exciting) & 0.60 & 1 & & & \\
Factor 2 (F2: Deceptive) & 0.54 & -0.15 & 1 & & \\
Factor 3 (F3: Taxing) & 0.66 & -0.14 & 0.39 & 1 & \\
Factor 4 (F4: Challenging) & 0.58 & 0.39 & 0.11 & 0.29 & 1 \\
\hline
\end{tabular}

Note: AVE stands for average variance extracted

Table 4 - Regression results predicting the perception of sales a career

\begin{tabular}{lcccc}
\hline & Beta & $\begin{array}{c}\text { Critical } \\
\text { Ratio }\end{array}$ & P-value & Decision \\
\hline Exciting => Pursuing sales career & 0.44 & 6.51 & 0.001 & Significant \\
Deceptive => Pursuing sales career & 0.038 & 0.56 & 0.57 & Not significant \\
Taxing => Pursuing sales career & -0.058 & -0.78 & 0.43 & Not significant \\
Competitive => Pursuing sales career & -0.085 & -1.13 & 0.25 & Not significant \\
\hline
\end{tabular}

Table 5 - Variation in students' perception based on country of birth

\begin{tabular}{llllll}
\hline \multirow{2}{*}{$\begin{array}{c}\text { Items of the Factor } \\
\text { 'Exciting' }\end{array}$} & \multicolumn{3}{c}{ Mean score } & & \\
\cline { 2 - 3 } & Australia & Asia & t-value & Sig. \\
\hline A sales job is likely to be interesting & 5.15 & 5.35 & 1.92 & 0.160 \\
A sales job is likely to be innovative & 5.16 & 5.58 & 8.41 & 0.004 \\
A sales job is likely to be exciting & 4.96 & 5.48 & 10.85 & 0.001 \\
A sales job is likely to be fun & 4.70 & 5.21 & 9.75 & 0.002 \\
\hline
\end{tabular}

Note: This output is based on the responses of Australian and Asian born students. 
Figure 1 - Structural path relationships - Factors influencing likelihood of pursuing a sales career

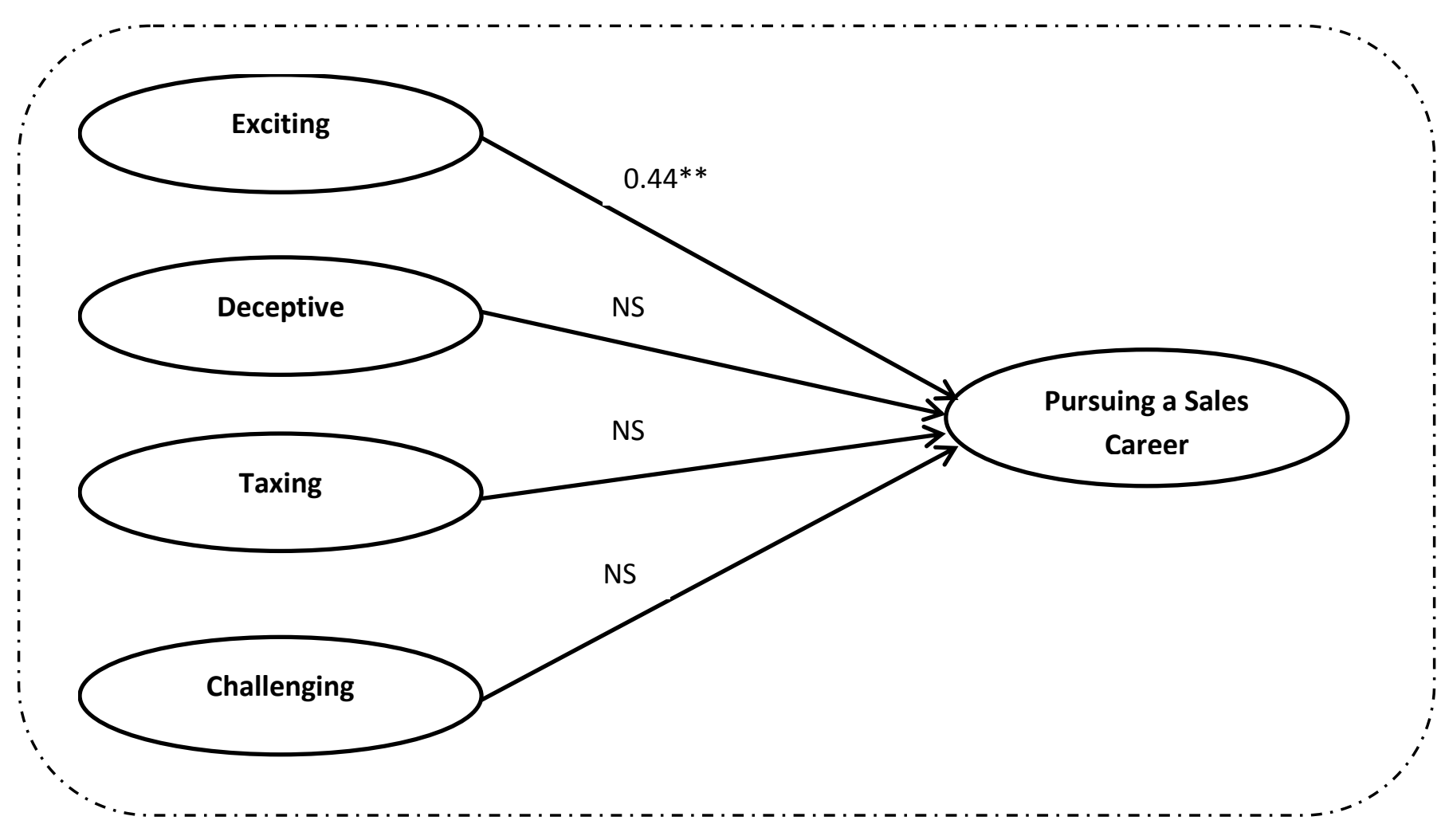

Note: ${ }^{* *}$ refers to significance at the $1 \%$ level of significance; NS refers to not significant 